\title{
Karakteristik Aliran Di Belakang Gundukan (Bump) Segitiga Pada Plat Datar
}

\author{
Setyo Hariyadi S.P. 1 \\ 1) Program Studi Teknik Pesawat Udara, Politeknik Penerbangan Surabaya \\ J. Jemur Andayani I/73, Wonocolo, Surabaya 60236 \\ Email: hudzaifahsetyo@ gmail.com
}

\begin{abstract}
Abstrak
Aliran viscous yang melewati sebuah pengganggu berbentuk bump, umumnya akan mengalami penurunan tekanan di sisi upstream dan kenaikan tekanan di sisi downstream. Saat momentum aliran fluida tidak dapat melawan kenaikan tekanan dan gesekan dengan permukaan maka aliran fluida akan terseparasi. Titik dimana mulai terjadi gejala separasi disebut titik separasi. Daerah setelah titik separasi mempunyai tekanan yang lebih kecil daripada daerah di sisi upstream sehingga mengakibatkan perbedaan tekanan yang besar. Akibat perbedaan tekanan ini, maka akan terjadi gaya drag pada benda. Bentuk bump yang digunakan pada studi numerik ini adalah segitiga dengan freestream sebesar $9.75 \mathrm{~m} / \mathrm{s}$ dan $15.5 \mathrm{~m} / \mathrm{s}$. Penelitian ini dilakukan dengan simulasi numerik mengunakan software simulasi dengan model turbulen $k-\varepsilon$ Realizable. Model benda uji berupa plat datar yang ditambahi dengan bump. Adanya bump pada pelat datar mengakibatkan aliran menjadi terseparasi sehingga menimbulkan penambahan gaya total drag sepanjang pelat datar. Separasi massive pada bump segitiga terjadi akibat momentum aliran tidak mampu mengatasi advarse pressure gradient dan tegangan geser antara permukaan bump dengan aliran fluida, sehingga untuk harga Re yang lebih besar akan mengakibatkan letak titik separasi lebih tertunda.
\end{abstract}

Kata Kunci: bump, koefisien tekanan $\left(C_{p}\right)$, koefisien pressure drag $\left(C_{D p}\right)$, koefisien total $\operatorname{drag}\left(C_{D}\right)$, profil kecepatan, titik separasi.

\begin{abstract}
Viscous flow characteristics through a contour has always been an interesting topic to study. In this study, the characteristic studied was turbulent flow across flat plate with bump. The aim of this research is to know the flow characteristic through the semicircular bump of the pressure coefficient distribution $\left(C_{p}\right)$ and the separation point. In addition, the flow visualization is done to get a flow picture across the flat plate with a bump. The bump form used in this numerical study is a triangular with a freestream of $9.75 \mathrm{~m} / \mathrm{s}$ and $15.5 \mathrm{~m} /$ $s$. This research is conducted by numerical simulation using simulation software with turbulent model $k-\varepsilon$ Realizable. Model of test specimen in the form of flat plate added with bump. The existence of a bump on the flat plate causes the flow to be terseparasi resulting in the addition of total drag force along the flat plate. Massive separation of the semicircular bump occurs as the flow momentum is unable to overcome adverse pressure gradient and the shear stress between the bump surface and the fluid flow, so for larger Re prices will result in the position of the separation point more delayed.
\end{abstract}

Keywords: Bump, pressure coefficient $\left(C_{p}\right)$, pressure drag coefficient $\left(C_{D p}\right)$, total drag coefficient $\left(C_{D}\right)$, speed profile, separation point.

\section{PENDAHULUAN}

Kemajuan ilmu manusia saat ini terutama dalam bidang mekanika fluida mendorong manusia untuk meneliti aliran fluida yang melintasi suatu benda. Hal ini terjadi karena pada kehid upan seharihari manusia tidak terlepas dari aliran fluida, misalnya angin yang melintasi suatu gedung atau bangunan dengan bentuk tertentu. Penelitian-penelitian tentang aliran fluida yang dilakukan bertujuan untuk mengetahui karakteristik aliran fluida pada saat melintasi suatu benda. 
Pada aliran fluida nyata selalu menunjukkan adanya suatu daerah yang alirannya terhambat, yaitu daerah di dekat permukaan yang kecepatan relatif terhadap permukaan bervariasi antara nol hingga 99\% kecepatan freestream. Daerah yang terhambat ini disebut lapisan batas (boundary layer). Konsep lapisan batas ini pertama kali diperkenalkan oleh Ludwig Prandtl dalam tahun 1904. Efekefek viskositas akan terkonsentrasi dalam lapisan batas ini (viscous region) sedangkan di luar lapisan batas efek viskositas dapat diabaikan (nonviscous region).

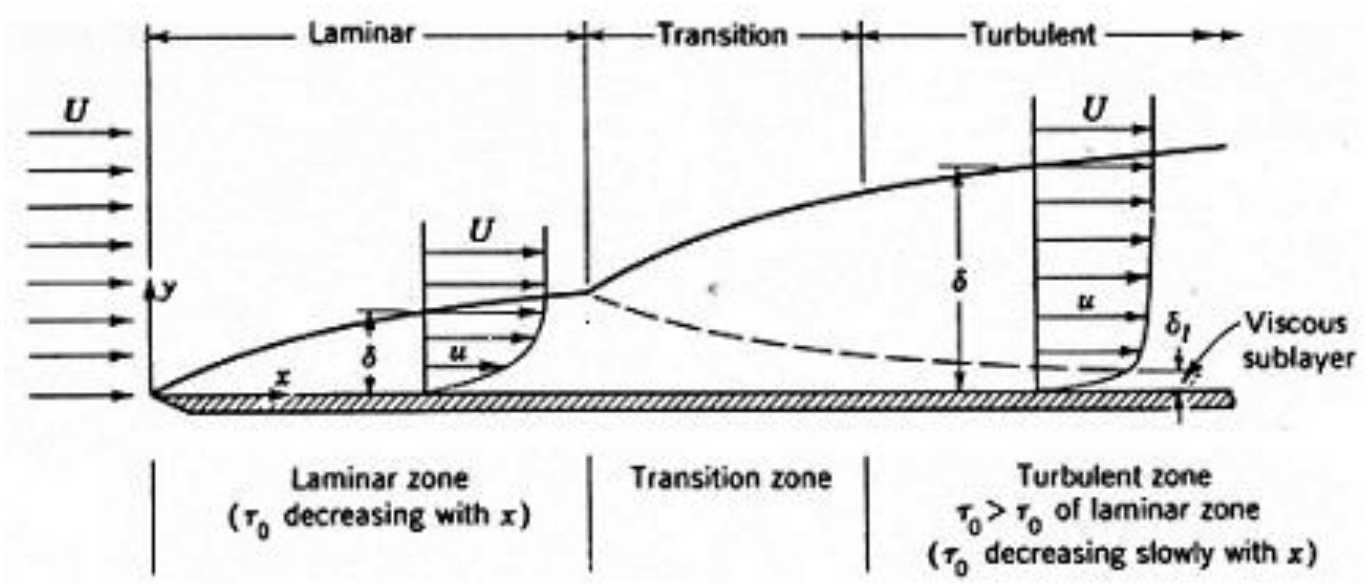

Gambar 1. Lapisan batas laminer dan turbulen sepanjang pelat datar.

Proses pembentukan lapisan batas dapat dilihat pada gambar 1. Ketika aliran melintasi pelat datar, pada bagian depan partikel-partikel fluida yang cukup dekat terhadap pelat dihambat oleh adanya tegangan geser yang besar. Lapisan batas menebal dalam arah yang sama dengan arah aliran. Pada lapisan batas ini terjadi perubahan kecepatan dari nol di permukaan pelat hingga kecepatan mendekati U pada jarak $\delta$.

Lapisan batas dapat dibedakan menjadi dua bagian yaitu lapisan batas laminer dan lapisan batas turbulen yang tergantung pada besarnya harga bilangan Reynolds. Di dalam aliran fluida proses peralihan dari aliran laminer ke turbulen disebut sebagai keadaan transisi. Faktor yang mempengaruhi lamanya proses transisi adalah gradien tekanan, kekasaran permukaan, gaya bodi dan gangguan aliran bebas. Begitu lapisan batas mulai menebal, ketidakstabilan pun terjadi dan mengakibatkan percampuran partikel (gerak acak) dan perubahan momentum dalam fluida hingga menyebabkan terbentuknya lapisan batas turbulen. Pada lapisan batas turbulen, profil kecepatan yang terbentuk lebih tebal (bundar) dengan gradien kecepatan di permukaan plat dan tegangan gesernya lebih tinggi daripada kondisi laminar maupun transisi.

Keberadaan pressure gradient di sepanjang permukaan benda padat mempunyai pengaruh yang sangat besar dan signifikan terhadap pertumbuhan boundary layer. Seperti aliran yang melintasi suatu silinder bulat (gambar 2). Gambar 2 menunjukkan pertumbuhan boundary layer pada permukaan silinder bulat yang mana pertumbuhannya lebih banyak dipengaruhi oleh adanya pressure gradient akibat bentuk silinder. Pada gambar tersebut tiap titik digambarkan dengan sumbu $\mathrm{x}$ searah kecepatan tangensial dan sumbu y yang tegak lurus sumbu x. Dimana U adalah kecepatan fluida ideal diluar boundary layer. 


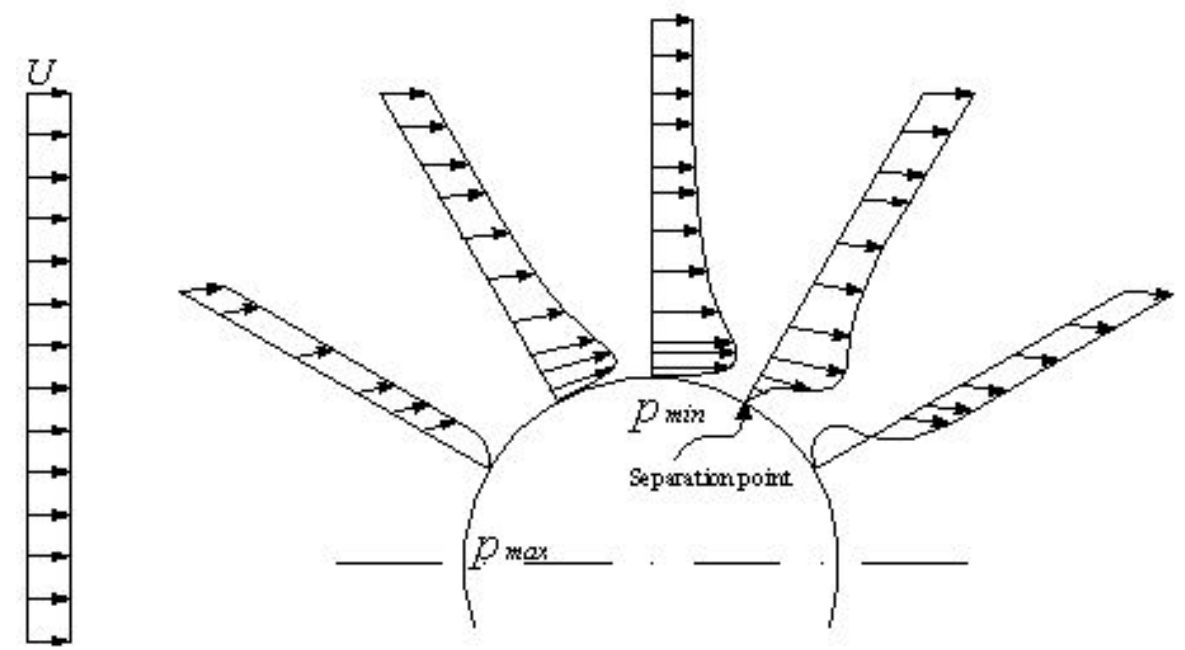

Gambar 2. Pertumbuhan boundary layer pada silinder bulat

Aliran viscous yang melewati bump berbentuk segitiga akan mengalami penurunan tekanan di sisi upstream dan kenaikan tekanan di sisi downstream. Saat momentum aliran fluida tidak dapat melawan kenaikan tekanan dan gesekan dengan permukaan maka aliran fluida akan terseparasi. Titik dimana mulai terjadi gejala separasi disebut titik separasi. Daerah setelah titik separasi mempunyai tekanan yang lebih kecil daripada daerah di sisi upstream sehingga mengakibatkan perbedaan tekanan yang besar. Akibat perbedaan tekanan ini maka akan terjadi gaya drag pada benda.

Kecepatan aliran fluida akan mencapai harga nol atau stagnasi di depan silinder, dan seiring dengan pergerakan aliran, kecepatannya akan bertambah besar sehingga mencapai harga maksimum pada bagian atas dari silinder. Setelah mencapai harga maksimum, kecepatan fluida akan berangsurangsur menurun saat fluida menuju ke daerah buritan (aft edge).

Seiring dengan kecepatan aliran fluida, tekanan pada permukaan benda padat juga akan mengalami perubahan yaitu berharga maksimum pada daerah depan dan berharga minimum pada daerah diatas silinder. Seperti yang ditunjukkan gambar 2 boundary layer mulai terjadi pada titik stagnasi depan, kemudian seiring dengan pergerakan aliran fluida, boundary layer mengalami pertumbuhan dimana ketebalannya akan semakin bertambah.

Pada saat bergerak ke bagian atas dari silinder, aliran fluida akan mengalami penurunan tekanan, atau pressure gradient lebih kecil dari nol $(d p / d x<0)$ dan disebut favourable pressure gradient. Dengan adanya favourable pressure gradient ini aliran fluida yang dekat dengan permukaan bergerak perlahan, dan terjadi kenaikan kecepatan.

Saat aliran fluida mencapai puncak silinder dan mulai bergerak turun ke daerah belakang silinder, aliran fluida akan mengalami kenaikan tekanan. Tekanan ini akan terus naik dan mencapai harga maksimum tepat pada titik separasi dan kemudian tekanannya konstan. Pressure gradient yang terjadi mulai dari puncak silinder ke daerah belakang silinder, harganya lebih besar dari nol ( $d p / d x>$ o) dan disebut adverse pressure gradient. Pada suatu titik dimana aliran tidak sanggup lagi mengatasi adverse pressure gradient bersama-sama dengan tegangan geser, maka pada saat itu aliran fluida di dalam boundary layer akan mengalami separasi dan titik tersebut dinamakan titik separasi. Di belakang titik separasi, terdapat sebagian fluida yang mengalami aliran balik, dan aliran fluida tidak mengikuti lagi bentuk dari solid body. Aliran fluida mulai tidak stabil dan terjadi pergolakan aliran. Daerah dimana terjadi pergolakan aliran disebut wake. 
Telah banyak penelitian yang berkaitan dengan pengontrolan boundary layer. Penelitian yang dilakukan Andi Joko (2001) mengenai pengaruh lokasi permukaan kasar sebagai inlet disturbance terhadap karakteristik boundary layer dan gejala separasi pada pelat melengkung didapatkan bahwa semakin besar jarak permukaan kasar terhadap pelat melengkung maka tingkat turbulensi aliran yang dibangkitkan lebih besar sehingga aliran mempunyai ketahanan yang lebih terhadap terjadinya separasi. Penelitian yang dilakukan Fatchan Nurul (2000) mengenai pengaruh inlet disturbance terhadap karakteristik boundary layer dan gejala separasi pada pelat melengkung didapatkan bahwa semakin besar kekasaran inlet disturbance maka tingkat turbulensi aliran yang dibangkitkan lebih besar sehingga aliran mempunyai ketahanan yang lebih terhadap terjadinya separasi. Dari kedua penelitian tersebut juga didapatkan bahwa semakin besar sudut kelengkungan pelat maka separasi akan terjadi lebih awal.

Penelitian tentang pengontrolan boundary layer lainnya dilakukan oleh Ari Susanto (2004) mengenai karakteristik turbulent boundary layer di sekitar alur berbentuk V tunggal yang melintang pada pelat datar. Dari penelitian tersebut didapatkan bahwa akibat adanya alur menyebabkan terjadinya kenaikan total drag serta timbul vortex quasi stabil dalam alur. Selain itu adanya alur mengakibatkan profil kecepatan turbulen yang terjadi relatif konstan dibandingkan dengan profil kecepatan turbulen yang terjadi pada pelat datar halus. Penelitian yang dilakukan M. Nuch (2004) mengenai karakteristik turbulent boundary layer setelah single square groove pada pelat datar didapatkan bahwa terjadi penurunan $C_{f}$ total di daerah setelah alur dibandingkan dengan $C_{f}$ total pada pelat datar halus. Berdasarkan penelitian-penelitian tersebut, maka muncul pemikiran untuk melakukan penelitian tentang aliran mele wati bump berbentuk segitiga tanpa diberi inlet disturbance dengan variasi 2 bilangan Reynolds.

\section{METODE}

Tujuan dari penelitian ini adalah untuk mengetahui karakteristik aliran melintasi bump berbentuk segitiga meliputi distribusi koefisien tekanan $\left(C_{p}\right)$ sepanjang pelat datar dan bump, profil kecepatan sebelum, sesudah dan di atas bump, titik separasi, perhitungan koefisien pressure drag $\left(C_{D p}\right)$ pada bump berdasarkan tekanan, perhitungan koefisien total drag $\left(C_{D}\right)$ sepanjang pelat datar berdasarkan perubahan momentum kecepatan sebelum dan sesudah melewati bump. Penelitian ini juga bertujuan untuk mendapat gambaran aliran yang melewati bump dengan visualisasi menggunakan asap. Variasi bilangan Reynolds yang digunakan yaitu terkait dengan kecepatan freestream $9,75 \mathrm{~m} / \mathrm{s}$ dan $15,5 \mathrm{~m} / \mathrm{s}$. Benda kerja yang digunakan adalah pelat datar yang terdapat gundukan (bump) berbentuk segitiga sedangkan detail dari gambar penelitian dapat dilihat pada gambar 3 dan 4.

Wall pressure tube terpasang pada permukaan pelat datar dan bump yang digunakan untuk mengukur tekanan statis aliran fluida. Sedangkan total pressure tube digunakan untuk mengukur tekanan stagnasi aliran fluida. Dari kedua tekanan tersebut dengan menggunakan persamaan Bernoulli dapat diperoleh tekanan dinamis aliran fluida. Manometer berfungsi untuk menyatakan besar tekanan yang diukur oleh wall pressure tube dan total pressure tube. Manometer yang digunakan ini mempunyai kemiringan sebesar $30^{\circ}$ dengan maksud untuk mempermudah pembacaan $\Delta \mathrm{h}$ terukur. Wind tunnel digunakan sebagai tempat pengujian benda uji. Alat ini mempunyai test section berbentuk persegi panjang dengan panjang $45 \mathrm{~cm}$, tinggi $30 \mathrm{~cm}$ dam lebar $30 \mathrm{~cm}$. Kecepatan maksimumnya $20 \mathrm{~m} / \mathrm{s}$ dan intensitas turbulensi sebesar $0.6 \%$. 


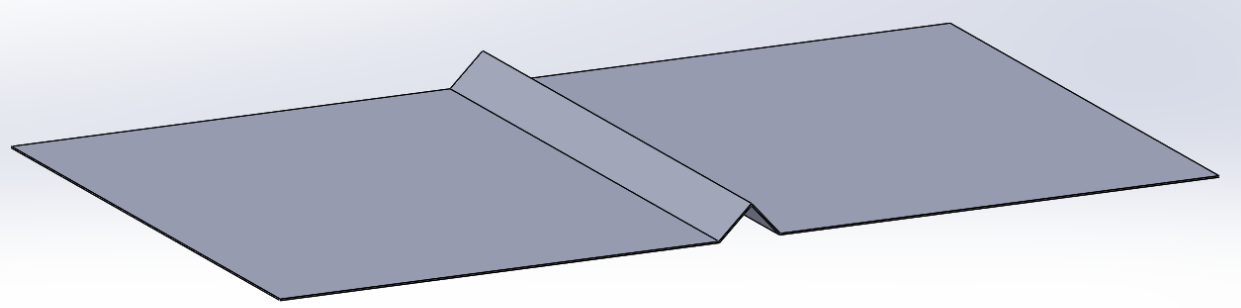

L

Gambar 3. Model bump segitiga
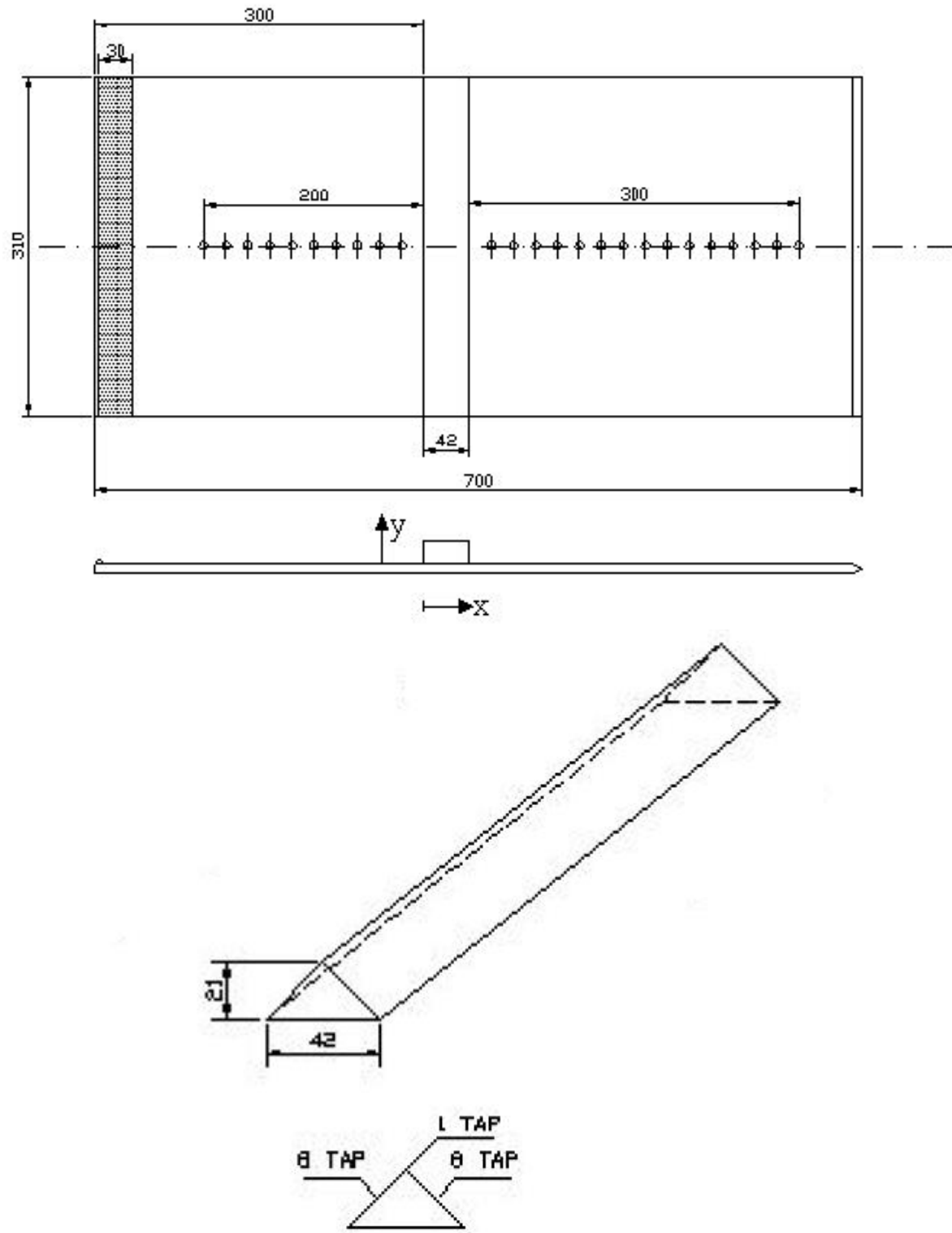

Gambar 4. Plat Datar dan Bump Segitiga 


\section{HASIL DAN PEMBAHASAN}

\section{Distribusi Koefisien Tekanan ( $C p$ ) Pada Pelat Datar Dengan Bump Berbentuk Segitiga}

Distribusi tekanan statis sepanjang pelat datar dan bump segitiga dalam bentuk koefisien tekanan $(C p)$ ditunjukkan pada gambar 5. Posisi dari bump terletak pada rentang $0.0 \leq x / w \leq 1.0$, disini $w$ menunjukkan lebar bump ke arah downstream. Dari gambar 4.3 terlihat bahwa pada daerah sebelum bump, aliran mengalami penurunan tekanan yang kecil meskipun melalui test section yang berpenampang konstan. Hal ini disebabkan adanya tegangan geser antara permukaan pelat datar dengan fluida yang mengakibatkan terjadinya penurunan tekanan. Kemudian aliran mengalami advarse pressure gradient pada saat mendekati bump. Adanya advarse pressure gradient ini mengakibatkan aliran mengalami perlambatan pada daerah dekat permukaan pelat datar, karena streamtube yang membesar pada saat aliran mendekati bump (aliran seolah-olah melalui luas penampang yang membesar).

Dari gambar 5 ditunjukkan bahwa untuk aliran dengan $R e=13000$ mengalami separasi bubble saat mendekati bump yaitu di titik $x / w=-0.25$ dan reattachment pada sisi upstream bump yaitu di titik $x / w=0.16$. Indikasi terjadinya separasi bubble ini yaitu adanya $C p$ yang konstan sepanjang titik tersebut. Sedangkan untuk aliran dengan $R e=21000$, separasi bubble yang terjadi terlalu kecil sehingga tidak terdeteksi. Hal ini dikarenakan untuk $R e=21000$ masih mempunyai cuk up energi untuk melawan efek dari perubahan permukaan yang tajam akibat adanya bump. Letak $C p$ maksimum untuk bump segitiga ini terjadi lebih ke belakang dibandingkan bump setengah lingkaran. Hal ini menunjukkan bahwa separasi bubble yang terjadi pada bump segitiga lebih besar daripada bump setengah lingkaran.

Aliran mengalami percepatan akibat favourable pressure gradient yang kuat di sisi upstream bump (sesudah titik reattachment dari separasi bubble) sampai puncak dari bump. Dari gambar 5 terlihat bahwa pada titik $x / w=0.5$ bump segitiga harga $C p=-1.23$ sedangkan dari gambar 4.2 terlihat bahwa pada $x / w=0.5$ bump setengah lingkaran harga $C p=-2.37$ untuk harga $R e=$ 21000. Hal ini mengindikasikan bahwa kecepatan aliran di puncak bump setengah lingkaran lebih besar daripada segitiga. Akibat sudut yang tajam dari puncak bump mengakibatkan aliran terseparasi. Separasi massive ini terjadi di puncak bump atau pada titik $x / w=0.5$ baik untuk $R e=$ 21000 ataupun $R e=13000$.

Aliran kembali mengalami percepatan setelah mengalami separasi sampai titik $x / w=3.75$ untuk $R e=21000$ dan $x / w=3.5$ untuk $R e=13000$ kemudian aliran mengalami perlambatan (gambar 5). Percepatan ini disebabkan karena adanya pengecilan luas penampang akibat efek dari daerah separasi yang membesar. Sedangkan perlambatan ini terjadi karena daerah separasi yang sebelumnya membesar kembali mengecil sampai akhirnya hilang sehingga mengakibatkan aliran mengalami perluasan penampang. Pengecilan daerah separasi ini disebabkan karena adanya transfer energi antara aliran yang berada di daerah yang tidak terseparasi menuju ke aliran yang berada di daerah yang terseparasi sehingga aliran yang terseparasi berangsur-angsur kembali normal. 


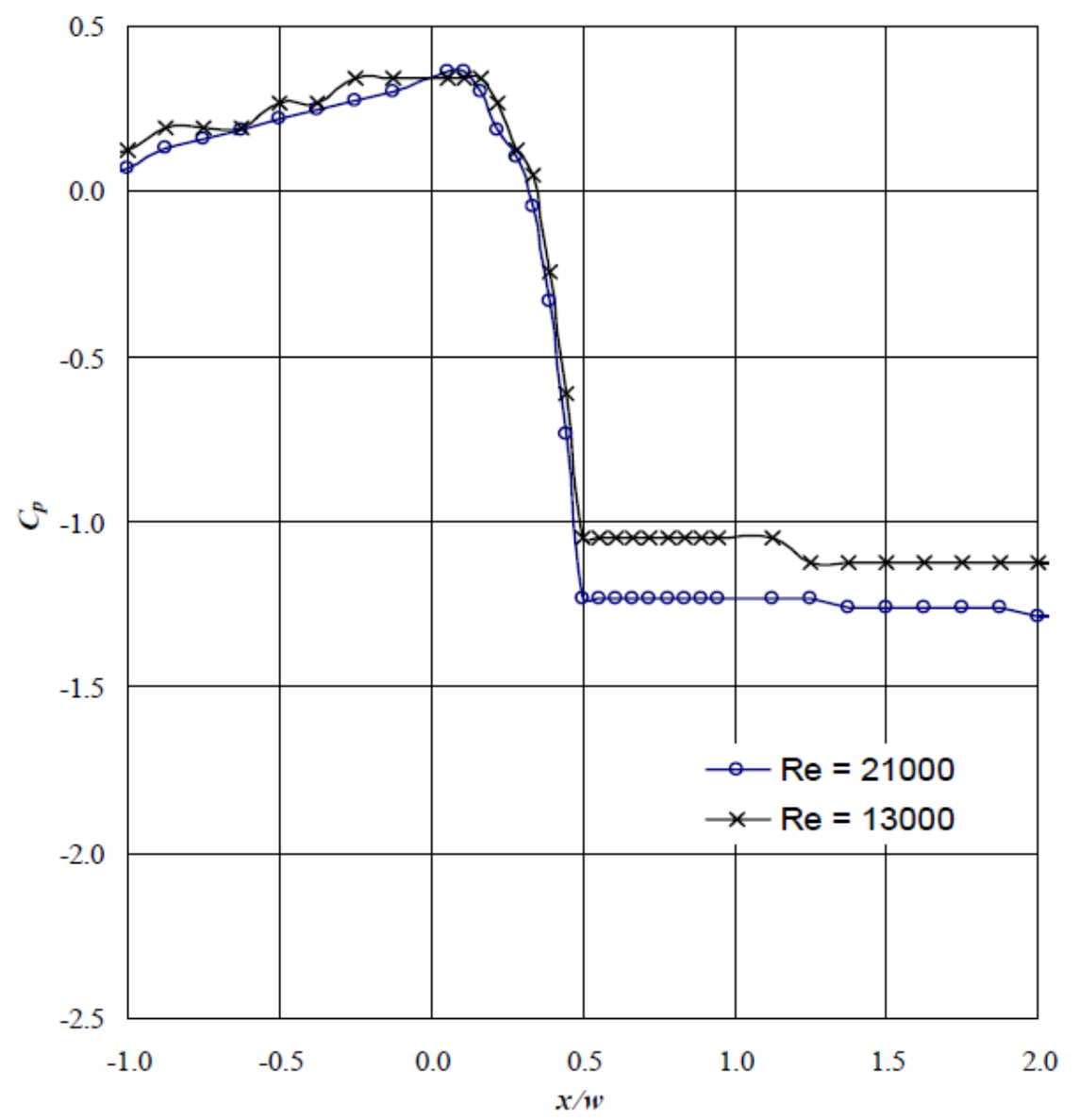

Gambar 5. Koefisien tekanan bump segitiga pada 2 bilangan Re yang berbeda

\section{Profil Kecepatan Pada Pelat Datar Dengan Bump Berbentuk Segitiga}

Profil kecepatan yang diukur sepanjang pelat datar dan bump segitiga dengan jarak antar profil sebesar $0.5 \mathrm{x} / \mathrm{w}$ ditunjukkan pada gambar 6 untuk $\mathrm{Re}=21000$ dan gambar 7 untuk $\operatorname{Re}=$ 13000. Posisi bump berada pada rentang $0.0 \leqslant \mathrm{x} / \mathrm{w} \leqslant 1.0$. Disini $\mathrm{w}$ menunjukkan lebar bump ke arah downstream. Skala gambar untuk $\Delta \mathrm{x} / \mathrm{w}=0.5$ sesuai dengan $\mathrm{u} / \mathrm{U}=1.0$. Pada gambar terdapat garis yang mewakili daerah separasi.

Gambar 6 dan gambar 7 menunjukkan bahwa aliran mengalami percepatan sebelum melewati bump pada daerah di atas boundary layer. Percepatan ini ditunjukkan oleh harga $\mathrm{u} / \mathrm{U}$ yang semakin membesar searah dengan aliran yang mendekati bump. Percepatan ini terjadi karena saat aliran mendekati bump, aliran mengalami perlambatan pada daerah dekat dengan permukaan pelat datar sehingga agar massa yang mengalir konstan maka aliran mengalami percepatan pada daerah di atas boundary layer. Saat aliran melewati bump juga terjadi percepatan aliran, percepatan aliran ini disebabkan oleh pengecilan luas permukaan akibat adanya bump. Percepatan ini ditunjukkan oleh profil kecepatan di $\mathrm{x} / \mathrm{w}=0.5$ untuk $\mathrm{Re}=21000$ yang mempunyai kecepatan $\mathrm{u} / \mathrm{U}=1.49$. Setelah melewati bump aliran akan mengalami perlambatan hingga kecepatannya kembali seperti semula. Pada bump setengah lingkaran profil kecepatan di titik $\mathrm{x} / \mathrm{w}=0.5$ mempunyai harga $\mathrm{u} / \mathrm{U}=1.78$ untuk $\operatorname{Re}=21000$, hal ini berarti kecepatan pada puncak bump setengah lingkaran lebih besar dibandingkan pada bump segitiga. Adanya perbedaan kecepatan ini dikarenakan boundary layer yang terbentuk pada puncak bump setengah lingkaran berkembang lebih tebal dibandingkan boundary layer yang terbentuk pada puncak bump segitiga karena pada puncak bump segitiga terjadi 
diskontinyu boundary layer sehingga luasan yang dilalui aliran fluida pada bump setengah lingkaran lebih kecil dibandingkan pada bump segitiga.

Akibat adanya sudut yang tajam di puncak bump tersebut mengakibatkan aliran mengalami separasi. Daerah separasi dibelakang bump ditunjukkan oleh profil kecepatan yang mempunyai harga $u / U=0$. Misalnya pada profil kecepatan $\mathrm{di} x / \mathrm{w}=1.5$ untuk $\operatorname{Re}=21000$, daerah separasi terjadi di $\mathrm{y}=0$ sampai $\mathrm{y}=26 \mathrm{~mm}$. Daerah separasi bump setengah lingkaran di titik yang sama terjadi di $\mathrm{y}=0$ sampai $\mathrm{y}=15.5 \mathrm{~mm}$, hal ini menunjukkan bahwa lebar separasi akibat adanya bump segitiga lebih besar daripada bump setengah lingkaran. Daerah separasi ini semakin lama semakin mengecil sampai akhirnya profil kecepatan kembali normal tanpa ada yang terseparasi. Dari gambar 6 dan gambar 7 diketahui bahwa titik reattachment terjadi di $\mathrm{x} / \mathrm{w}=7.0$ untuk $\operatorname{Re}=21000$ maupun $\operatorname{Re}$ $=13000$. Titik reattachment pada bump segitiga lebih ke belakang dibandingkan bump setengah lingkaran. Hal ini menunjukkan bahwa besar daerah separasi untuk bump segitiga lebih besar daripada bump setengah lingkaran.

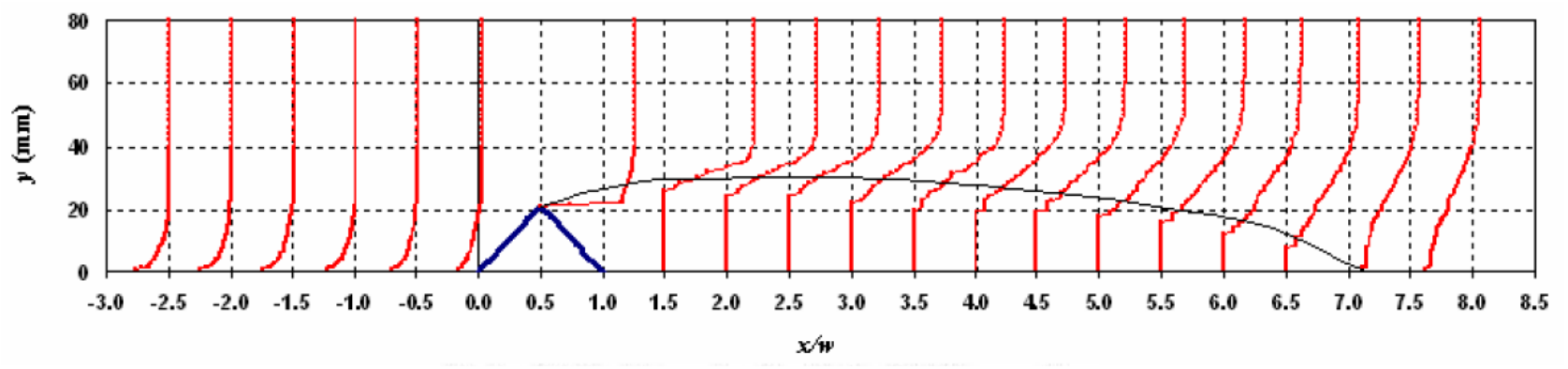

Gambar 6. Profil kecepatan $\mathrm{u} / \mathrm{U}$ untuk $\mathrm{Re}=21000$ bump segitiga

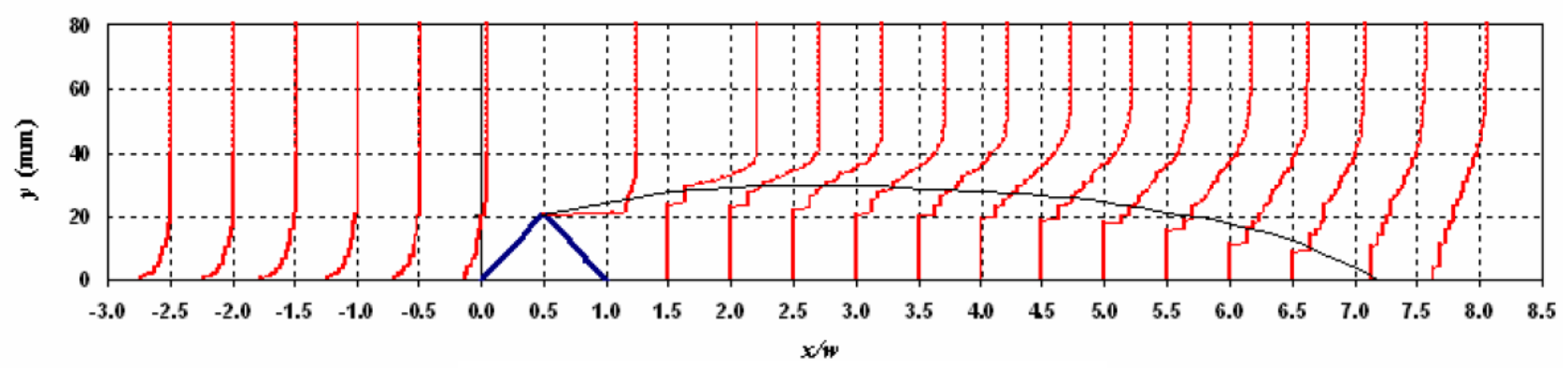

Gambar 7. Profil kecepatan u/U untuk $\mathrm{Re}=13000$ bump segitiga

\section{PENUTUP}

\section{Simpulan}

Dari analisa hasil pengujian aliran melintasi pelat datar dengan bump berbentuk segitiga dengan kecepatan freestream $9.75 \mathrm{~m} / \mathrm{s}$ dan $15.5 \mathrm{~m} / \mathrm{s}$ dapat diambil beberapa kesimpulan sebagai berikut :

1. Pada bump segitiga separasi massive terjadi karena advarse pressure gradient yang tajam akibat perubahan sudut yang tajam permukaan bump, sehingga letak titik separasi massive tidak dipengaruhi oleh harga $R e$.

2. Daerah wake yang lebih besar mengakibatkan gaya total drag yang bekerja juga semakin besar. Semakin besar kecepatan aliran maka letak titik rettachment aliran terseparasi terjadi semakin awal. 


\section{DAFTAR PUSTAKA}

[1]. Andi Joko, 2001, "Studi Eksperimental Pengaruh Lokasi Permukaan Kasar Sebagai Inlet Disturbance Terhadap Karakteristik Boundary Layer Dan Gejala Separasi Pada Pelat Lengkung", Laporan Tugas Akhir, Jurusan Teknik Mesin FTI - ITS.

[2]. Ari Susanto, 2004, "Experimental Study of Turbulent Boundary Layer Characteristic Around a Singgle Transverse "V" Groove on the Flat Plate", Laporan Tugas Akhir, Jurusan Teknik Mesin FTI - ITS.

[3]. Bard Venas and Lars R. Saetran, 1999, Space-Time Correlations in Separated Flow Behind a Surface Mounted Obstacle, Department of Mechanics, Thermo and Fluid Dynamics Norwegian University of Science and Technology N-7034 Trondheim, Norway.

[4]. Fatchan Nurul, 2000, "Studi Eksperimental Pengaruh Inlet Disturbance Terhadap Karakteristik Boundary Layer Dan Ge jala Separasi Pada Pelat Lengkung", Laporan Tugas Akhir, Jurusan Teknik Mesin FTI - ITS.

[5]. Fox, Robert W. and McDonald, Alan T, 1994, Introduction to Fluid Mechanics, $4^{\text {th }}$ edition, John Wiley and Son, Inc.

[6]. M. Nuch, 2004, "Studi Eksperimental Karakteristik Turbulent Boundary Layer setelah Single Square Groove pada palat datar", Laporan Tugas Akhir, Jurusan Teknik Mesin FTI ITS.

[7]. Mulvany, Nicholas J., Li Chen, Jiyuan Y. Tu and Brendon Anderson (2004), Steady State Evaluation of Two Equation RANS Turbulence Models for High Reynolds Number Hydrodynamic Flow Simulations, Final Report, Defence Science and Technology Organisation, Departement of Defence, Australian Goverment 